\title{
Analisis Faktor-Faktor Yang Mempengaruhi Pilihan Perusaahan Terhadap Konservatisme Akuntansi Pada Perusahaan Manufaktur Yang Terdaftar Di BEI
}

\section{Evi Vidiana ${ }^{a}$, Diana Dwi Astuti ${ }^{\mathrm{b}}$, Wiwik Fitria Ningsih ${ }^{\mathrm{c}}$}

${ }^{a}$ Prodi Akuntansi STIE Mandala, evividiana070@gmail.com

${ }^{b}$ Prodi Akuntansi STIE Mandala, diana@stie-mandala.ac.id

${ }^{c}$ Prodi Akuntansi STIE Mandala, wiwik@stie-mandala.ac.id

E - mail Koresponden

\section{N F O A R T I K E L}

\section{Riwayat Artikel:}

Artikel Dikirim 05-08-2020

Revisi 20-08-2020

Artikel Diterima14-09-2020

Keywords: Conservatism, Public ownership, Debt covenant, Growth opportunities, Capital intensity

Kata Kunci: Konservatisme, Kepemilikan publik, Perjanjian hutang, Peluang pertumbuhan, Intensitas modal

:wiwik@stie-mandala.ac.id

\section{A B S T R A C T}

The principle of accounting conservatism is still considered a controversial principle on the one hand accounting conservatism is considered as an obstacle that will affect the accounting conservatism as the dependent variable, then managerial ownership quality of financial statements, on the other hand accounting conservatism is useful to avoid managers' opportunistic behavior with regard to contracts used by financial statements as contract media. used in this research is, public ownership, debt governance, grow opportunities and capital intensity are used as factors that can influence conservatism as well as being an independent variable. The sample of this research is manufacturing companies listed on the Indonesian stock exchange (IDX). Samples are selected using the purposive sampling method. The number of companies taken as samples are 5 companies from 14 companies in 2014-2018. The results of research from research this is that from the five variables namely managerial ownership, public ownership, debt covenant, growth opportunities and capital intensity, there are three variables that have a significant influence on accounting conservatism.

\section{A B S T R A K}

Prinsip konservatisme akuntansi masih dianggap sebagai prinsip yang kontroversial di satu sisi konservatisme akuntansi dianggap sebagai suatu kendala yang akan mempengaruhi kualitas laporan keuangan, di sisi lain konservatisme akuntansi berguna untuk menghindari perilaku oportunistik manajer sehubungan dengan kontrak yang digunakan. berdasarkan laporan keuangan sebagai media kontrak. Yang digunakan dalam penelitian ini adalah konservatisme akuntansi sebagai variabel terikat, kemudian kepemilikan manajerial, kepemilikan publik, tata kelola hutang, peluang tumbuh dan intensitas modal digunakan sebagai faktor yang dapat mempengaruhi konservatisme serta menjadi variabel bebas. Sampel penelitian ini adalah perusahaan manufaktur yang terdaftar di Bursa Efek Indonesia (BEI). Sampel dipilih dengan menggunakan metode purposive sampling. Jumlah perusahaan yang diambil sebagai sampel adalah 5 perusahaan dari 14 perusahaan pada tahun 2014-2018. Hasil penelitian dari penelitian ini yaitu dari lima variabel yaitu kepemilikan manajerial, kepemilikan publik, debt covenant, peluang tumbuh dan intensitas modal, terdapat tiga variabel yang berpengaruh signifikan terhadap konservatisme akuntansi. 


\section{PENDAHULUAN}

Laporan keuangan yang dibuat oleh perusahaan adalah salah satu informasi yang menggambarkan aktivitas atau kinerja manajemen yang telah dipercaya untuk mengelola sumber daya perusahaan. Informasi yang disampaikan melalui laporan keuangan ini salah satu sumber informasi yang penting bagi pihak internal dan pihak eksternal dalam pengambilan keputusan. Astarini (2011) menyebutkan bahwa laporan keuangan ini salah satu informasi penting bagi pihak internal selain informasi lainnya, seperti informasi industri, kondisi perekonomian, pangsa pasar, serta kualitas manajemen dan lainnya Banyak penelitian yang telah dilakukan mengenai faktor-faktor yang dapat mempengaruhi konservatisme, namun hasil yang ditemukan masih banyak beragam. Penelitian ini mengacu pada penelitian yang dilakukan oleh Sari dan Adhariani (2009) yang menggunakan faktor-faktor seperti rasio leverage, yang digunakan untuk menjelaskan debt covenant hypothesis pada teori akuntansi positif, dan ukuran perusahaan, risiko perusahaan, rasio konsentrasi, lalu intensitas modal sebagai proksi dari political cost hypothesis pada teori akuntansi positif. Faktor-faktor lainnya yaitu pada penelitian yang dilakukan oleh Ardina (2012) seperti kepemilikan manajerial dan kepemilikan publik, yang digunakan untuk menjelaskan bonus plan hypothesis pada teori akuntansi positif, dan selain itu faktor kesempatan tumbuh (growth opportunities) dalam penelitian Astarini (2011). Variabel yang digunakan dalam penelitian ini adalah konservatisme akuntansi sebagai variabel dependen, lalu kepemilikan manajerial, kepemilikan publik, debt covenant, growth opportunities dan intensitas modal digunakan sebagai faktor-faktor yang dapat mempengaruhi konservatisme sekaligus menjadi variabel independen.Tujuan penelitian ini Untuk mengetahui secara empiris pengaruh kepemilikan manajerial, kepemilikan publik, debt covenant, growth opportunities dan intensitas modal terhadap pilihan konservatisme akuntansi

\section{KAJIAN PUSTAKA DAN PERUMUSAN HIPOTESIS}

\section{Penelitian Terdahulu}

Beberapa penelitian terdahulu mengenai masalah yang sama yaitu tentang konservatisme dengan berbagai faktor-faktornya diantaranya sebagai berikut:

Cynthia Sari dan Desi Adhariani (2009) dengan judul "Konservatisme Perusahaan di Indonesia dan Faktor-Faktor Yang Mempengaruhinya“, dimana variabel 
dependennya konservatisme, sedangkan variabel independennya debt/equity hypothesis (yang diproksi oleh tingkat leverage), dan size hypothesis (Ukuran perusahaan, risiko perusahaan, rasio konsentrasi, dan intensitas modal). Hasil penelitiannya adalah adanya hubungan negatif antara rasio leverage dengan konservatisme akuntansi, sedangkan Dwi Astarini (2011) dalam penelitian yang berjudul "Analisis Faktor - Faktor Yang Mempengaruhi Pilihan Perusahaan Terhadap Konservatisme Akuntansi” menggunakan variabel dependen konservatisme akuntansi, kemudian untuk variabel independennya adalah struktur kepemilikan, debt covenant, growth opportunities. Hasil penelitiannya menyatakan bahwa debt covenant dan growth opportunities tidak berpengaruh terhadap konservatisme akuntansi.

Penelitian selanjutnya adalah penelitian yang dilakukan oleh Deffa Agung Nugroho (2012) dengan judul "Pengaruh Struktur Kepemilikan Manajerial, Debt Covenant, Tingkat Kesulitan Keuangan Perusahaan, Dan Risiko Litigasi Terhadap Konservatisme Akuntansi". Hasil dari penelitian ini adalah kepemilikan manajerial dan tingkat kesulitan keuangan berpengaruh negatif terhadap konservatisme akuntansi.

Dyahayu Artika Deviyanti (2012) menyatakan dalam penelitiannya yang berjudul "Analisis Faktor-Faktor Yang Mempengaruhi Penerapan Konservatisme Dalam Akuntansi (Studi pada Perusahaan Manufaktur yang Terdaftar di Bursa Efek Indonesia)" bahwa kepemilikan manajerial, kepemilikan institusional dan kepemilikan publik berpengaruh negatif terhadap konservatisme.

\section{Landasan Teori}

\section{Pengertian Konservatisme Akuntansi}

Dalam penyajian laporan keuangan, akuntan dapat memilih metode akuntansi apa yang akan diterapkan. Dalam konservatisme, akuntan dihadapkan dalam pilihan dua atau lebih teknik akuntansi. Menurut FASB Statement of Concept No.2 dalam Sari (2004): "Konservatisme adalah reaksi hati-hati untuk menghadapi ketidakpastian dalam mencoba memastikan bahwa ketidakpastian dan risiko pada situasi bisnis telah dipertimbangkan." Definisi konservatime menurut Wibowo dalam Widya (2004): "Konservatisme merupakan prinsip yang penting dalam pelaporan keuangan agar pengakuan dan pengukuran aktiva serta laba dilakukan dengan penuh kehati-hatian, karena aktivitas ekonomi dan bisnis dilingkupi oleh ketidakpastian." 


\section{Faktor - Faktor Pemilihan Konservatisme}

Beberapa asumsi yang didasarkan pada Standar Akuntansi Keuangan (SAK, 2015) tentang faktor-faktor yang dapat mempengaruhi pilihan perusahaan dalam akuntansi konservatif adalah sebagai berikut:

\section{1) Metode persediaan LIFO}

Metode LIFO (Last In First Out) merupakan metode penetapan harga pokok persediaan berdasarkan asumsi bahwa harga pokok terjual harus dibebankan ke pendapatan menurut biaya yang paling akhir terjadi, dengan menggunakan LIFO, biaya unit yang dijual merupakan biaya pembelian paling akhir (Warren dkk, 2005:461). Dalam (Dewi:2003). Metode yang paling konservatif dalam penilaian persediaan adalah metode LIFO, sedangkan yang paling optimis adalah metode FIFO. Hal itu dikarenakan LIFO cenderung menghasilkan laba yang lebih rendah daripada FIFO, bila harga meningkat persediaan yang dihitung menggunakan LIFO akan lebih rendah daripada menggunakan FIFO, bila persediaan akhir lebih kecil, maka harga pokok penjualan akan lebih besar dan laba akan lebih kecil.

\section{2) Metode penyusutan double declining balance}

Metode penyusutan double declining balance (metode saldo menurun) merupakan metode penyusutan yang jumlah pembebanan beban penyusutan aktiva semakin menurun selama taksiran umur aktiva tersebut. Metode ini menghasilkan beban yang semakin turun sepanjang estimasi umur aktiva (Warren Reeve Fess, 2005:512), jika periode penyusutan semakin pendek, maka semakin konservatif dan Jika periode penyusutan semakin panjang, maka semakin optimis. Metode penyusutan ini lebih konservatif daripada metode garis lurus, karena menghasilkan cost yang lebih tinggi sehingga menghasilkan laba yang relatif kecil (Dewi, 2003).

\section{3) Metode amortisasi saldo menurun}

Metode amortisasi saldo menurun merupakan alokasi pembebanan periodik dari biaya aktiva tak berwujud yang semakin menurun, jika periode amortisasi semakin pendek, maka lebih konservatif dan jika periode amortisasi semakin panjang maka semakin optimis. Metode amortisasi ini lebih konservatif karena menghasilkan cost yang lebih tinggi sehingga laba menjadi kecil (Dewi, 2003).

\section{4) Pengakuan biaya riset dan pengembangan sebagai cost}

Biaya riset dan pengembangan bukan merupakan aktiva tak berwujud, tetapi aktivitas 
riset dan pengembangan menghasilkan pengembangan sesuatu yang dipatenkan atau diperoleh hak ciptanya seperti produk, rumus maupun hasil sastra baru (Kieso, 2007:90). Menurut (Dewi, 2003) perusahaan memungkinkan memilih metode yang sesuai dengan keadaan perusahaan, jika biaya riset dan pengembangan diakui sebagai cost pada periode berjalan maka perusahaan menghasilkan laporan 
yang cenderung konservatif dan bila biaya riset dan pengembangan diakui sebagai aktiva, maka laporan keuangan cenderung optimis.

\section{5) Struktur Kepemilikan}

Kepemilikan merupakan salah satu faktor intern perusahaan yang menentukan kemajuan perusahaan. Pemilik atau biasa disebut dengan pemegang saham merupakan penyedia dana yang dibutuhkan perusahaan. Tanpa pemegang saham perusahaan tidak dapat berdiri dan tidak dapat memiliki dana dalam membangun, memperluas dan mengoperasikan usaha bisnisnya. Pemegang saham selaku pemilik perusahaan mempunyai hak- hak dasar, (Albridge dan Sutojo:74) diantaranya :

a) Hak-hak yang berkaitan dengan kepemilikan perusahaan.

b) Hak-hak yang berkaitan dengan memutuskan hal-hal penting.

\section{6) Kepemilikan Institusional}

Suatu perusahaan dapat saja dimiliki oleh institusi yaitu lembaga yang memiliki kepentingan besar terhadap investasi yang dilakukan termasuk investasi saham. Institusi menyerahkan tanggung jawab kepada divisi tertentu untuk mengolah investasi pada perusahaan tersebut. Institusi hanya memantau secara profesional perkembangan investasinya dengan meningkatkan pengendalian terhadap tindakan manajemen sehingga potensi kecurangan dapat ditekan, keberadaan institusi ini mampu menjadi alat monitoring yang efektif bagi perusahaan. Investor institusional perusahaan publik antara lain terdiri dari dana pensiun, perusahaan asuransi, perusahaan dana reksa, dan investment fund yang dibentuk perusahaan-perusahaan asuransi. Peranan investor institusional antara lain berbentuk :

a) Mengarahkan dan memonitor arah kegiatan bisnis perusahaan (Directing and Controlling).

b) Sumber informasi perusahaan (Source of company's information)

c) Pengajuan suara dalam rapat pemegang saham (Voting).

\section{7) Kepemilikan Manajerial}

Dibandingkan dengan investor institusional, jumlah pemegang saham oleh investor manajerial pada setiap perusahaan publik biasanya kecil. Investor 
manajerial biasanya terdiri dari pengelola perusahaan seperti Dewan Direksi dengan Dewan Komisaris, karena jumlah kepemilikan saham yang kecil tersebut banyak investor manajerial tidak begitu memperdulikan hak mereka menghadiri rapat pemegang saham (RUPS), melakukan voting atau ikut memilih ketua dan anggota Board of Directors.

\section{8) Debt Covenant (Kontrak Utang)}

Rasio Long Term Debt to Total Asset menggambarkan struktur modal perusahaan. Dimana struktur modal adalah merupakan perimbangan jumlah utang jangka pendek yang bersifat permanen, utang jangka panjang, saham preferen dan saham biasa Sartono (2001:225). Sartono (2001:230) menjelaskan bahwa teori Modigliani-Miller memperkenalkan teori struktur modal dengan asumsi sebagai berikut :

a) Resiko bisnis perusahaan dapat diukur dengan standar deviasi laba sebelum bunga dan pajak (EBIT) dan perusahaan yang memiliki resiko bisnis sama dikatakan berada dalam kelas yang sama.

b) Semua investor dan investor potensial memiliki estimasi sama terhadap EBIT perusahaan dimasa yang akan datang. Rasio Long Term Debt to Total Asset merupakan rasio untuk mengukur dimana aktiva perusahaan dibiayai dengan utang, jadi semkin besar proporsi utang yang digunakan oleh perusahaan, pemilik modal akan menanggung resiko yang besar pula.

\section{9) Kesempatan Tumbuh (Growth Opportunities)}

Pertumbuhan merupakan elemen yang terjadi dalam siklus perusahaan. Ukuran pertumbuhan dalam perusahaan tergantung dari kegiatan perusahaan. Pengertian pertumbuhan dalam manajemen keuangan pada umumnya menunjukkan peningkatan ukuran skala perusahaan. Dalam penelitian ini variabel yang digunakan adalah kesempatan tumbuh (growth opportunities). Growth Opportunities adalah kesempatan perusahaan untuk melakukan investasi pada hal-hal yang menguntungkan. Untuk mengidentifikasi growth opportunities adalah dengan menggunakan rasio market value to book value dari total assets. Perusahaan-perusahaan yang mempunyai growth opportunities yang baik akan mempunyai rasio market to book yang lebih besar daripada perusahaan yang 
tidak mempunyai growth opportunities (Gaud et al, 2003). Namun menurut Harris dan Raviv (1991) rasio market value to book value to total assets tidak semestinya digunakan untuk mengukur growth opportunities, hal ini dikarenakan sifat aset yang akan mengalami peningkatan nilai dari waktu ke waktu.

\section{0) Kepemilikan Publik}

Kepemilikan publik adalah jumlah saham perusahaan yang dimiliki publik atau masyarakat selain dari manajemen dan instutisional. Menurut Deviyanti (2012), Struktur kepemilikan publik merupakan persentase jumlah saham yang dimiliki oleh publik dibandingkan dengan jumlah seluruh saham yang beredar, semakin menyebarnya kepemilikan publik maka semakin rendah pengendalian, hal ini disebabkan banyaknya pemilik saham perusahaan namun masing-masing hanya memiliki jumlah saham yang sedikit, dengan kondisi seperti ini manajemen akan dapat dengan mudah melakukan manajemen laba karena adanya fleksibilitas dalam menyajikan informasi laporan keuangan, hal tersebut sesuai dengan plan bonus hypothesis, bahwa manajemen akan menaikan nilai laba agar kinerja perusahaan terlihat bagus oleh pemilik atau para pemegang saham yang mengharapkan dividen atau capital gain yang besar, dengan begitu manajemen akan mendapatkan bonus atas kinerja tersebut, hasilnya adalah pelaporan atas laba menjadi tidak konservatif.

\section{1) Intensitas Modal}

Intensitas merupakan kekuatan atau kemampuan, sedangkan modal adalah asetaset, baik aset lancar maupun tidak lancar, yang dapat digunakan untuk melakukan proses produksi. Intensitas modal termasuk dalam indikator yang dapat digunakan untuk mengamati biaya politik perusahaan, jadi dapat diartikan intensitas modal adalah kemampuan atau kekuatan perusahaan atas aset yang dimiliki oleh perusahaan tersebut untuk melakukan proses produksi hingga ke penjualan. Pernyataan tersebut didukung oleh Fitri (2008) yang menyatakan intensitas modal disebut juga dengan rasio perputaran total aktiva (total assets turnover) atau perputaran modal (capital turnover). Intensitas modal menunjukan perbandingan antara jumlah aktiva yang 
digunakan dalam operasi (operating assets) dengan jumlah penjualan yang diperoleh selama periode tertentu. Jadi dengan rasio ini dapat perusahaan melihat keefisienan aktiva yang dimiliki perusahaan dalam penggunaannya, seperti yang dikatakan Syamsuddin (2000), rasio intensitas modal ini dapat menunjukan tingkat efisiensi penggunaan seluruh aktiva perusahaan dalam menghasilkan jumlah penjualan perusahaan. Ada beberapa kelemahan dalam menaksir rasio intensitas modal. Munawir (1998) menyatakan tiga kelemahan penggunaan rasio intensitas modal antara lain:

a) Keterbatasan ruang lingkup rasio intensitas modal

b) Perbedaan periode antara rasio intensitas modal dengan penjualan

c) Faktor-faktor lain yang mempengaruhi penjualan

\section{METODA PENELITIAN}

Sumber data yang digunakan dalam penelitian ini diperoleh dari laporan keuangan perusahaan manufaktur sektor industri barang konsumsi sub sektor makanan dan minuman yang mempublikasikan laporan keuangan perusahaannya pada situs http://www.idx.com. Laporan keuangan yang digunakan.

Populasi yang akan menjadi objek dalam penelitian ini adalah seluruh perusahaan manufaktur sektor industri barang konsumsi sub sektor makanan dan minuman yang telah tercatat dan menerbitkan laporan keuangan di Bursa Efek Indonesia dari tahun 2014-2018. Berdasarkan data pada http://www.sahamok.com ada 14 perusahaan manufaktur sub sektor makanan dan minuman yang tercatat di situs resmi BEI dalam penelitian ini adalah laporan keuangan tahun 2014-2018

\section{Indentifikasi Operasional Variabel.}

a.Variabel Dependen

Menurut Sekaran (2003) variabel dependen atau variabel terikat adalah variabel yang dijelaskan atau dipengaruhi oleh variabel independen atau variabel bebas. Variabel dependen pada penelitian ini adalah Konservatisme Akuntansi (Y).

b. Variable Independen

Menurut Sekaran (2003) variabel independen atau variabel bebas adalah variabel yang membantu menjelaskan varians dalam variabel terikat. Variabel independen yang digunakan dalam penelitian ini sebagai berikut: 
$X_{1}=$ Kepemilikan Manajerial

$X_{2}=$ Kepemilikan Publik

$X_{3}=$ Debt Covenant

$X_{4}=$ Growth Opportunities

$X_{5}=$ Intensitas Modal

Metode pengumpulan data yang dilakukan adalah sebagai berikut :

1) Penelitian Kperpustakaan .

2) Dokumentasi.

Metode analisis data yang digunakan adalah sebagai berikut :

1) Analisis Regresi Logistik

2) Pengukuran Variabel penelitian

\section{ANALISIS DAN PEMBAHASAN}

\section{Hasil Analisis Penelitian}

\section{a. Uji Kelayakan Model Regresi}

Langkah awal untuk mengetahui bahwa suatu model regresi logistik merupakan sebuah model yang tepat, terlebih dahulu akan dilihat bentuk kecocokan atau kelayakan model secara keseluruhan. Kelayakan model regresi dinilai dengan menggunakan Hosmer and Lemeshow's Goodness of Fit Test.

\section{Tabel 1. Hasil Uji Kelayakan Model Regresi}

Hosmer and Lemeshow Test

\begin{tabular}{|l|r|r|r|}
\hline Step & Chi-square & df & Sig. \\
\hline 1 & 5.245 & & 6 \\
\hline
\end{tabular}

Dari tabel diatas menunjukkan bahwa nilai dari pengujian Hosmer and Lemeshow's Goodness of Fit Test nilai chi square adalah 5,245 dengan signifikansi sebesar 0.513. Dengan tingkat signifikansi lebih besar dari tingkat $\alpha$ sebesar 0,1 maka H0 diterima dan berarti model mampu memprediksi nilai observasinya atau dapat dikatakan model dapat diterima karena cocok dengan data observasinya.

\section{b.Uji Model Fit (Overall Model Fit)}

1) Chi Square Test 
Menurut Ghozali (2006:268) uji chi square untuk keseluruhan model terhadap data dilakukan dengan membandingkan nilai antara -2 log likelihood pada awal (hasil block number 0) dengan nilai -2 log likelihood pada akhir (hasil block number 1). Apabila terjadi penurunan, maka model tersebut menunjukkan model regresi yang baik. Penurunan -2 log likelihood dapat dilihat pada tabel berikut :

Tabel 2. Hasil Chi Square Test

\begin{tabular}{|c|c|c|c|}
\hline \multicolumn{4}{|c|}{ Iteration History ${ }^{a, b, c}$} \\
\hline \multirow{2}{*}{\multicolumn{2}{|c|}{ Iteration }} & $-2 \log$ & Coefficients \\
\hline & & likelihood & Constant \\
\hline \multirow[t]{3}{*}{ Step 0} & 1 & 34.296 & -.240 \\
\hline & 2 & 34.296 & -.241 \\
\hline & 3 & 34.296 & -.241 \\
\hline
\end{tabular}

Tabel 3. Hasil Logistic Regression Iteration History $\mathbf{a , b , c , d}$

\begin{tabular}{|c|c|c|c|c|c|c|c|}
\hline \multirow[b]{2}{*}{ Iteration } & \multirow{2}{*}{$\begin{array}{l}-2 \text { Log } \\
\text { likelihood }\end{array}$} & \multicolumn{6}{|c|}{ Coefficients } \\
\hline & & Constant & $\mathrm{KM}$ & $\mathrm{KP}$ & $\mathrm{DC}$ & $\mathrm{GO}$ & IM \\
\hline Step 11 & 26.257 & 1.059 & .276 & .052 & .204 & -.012 & -3.972 \\
\hline 2 & 24.652 & 3.825 & .446 & .122 & .316 & -.022 & -8.874 \\
\hline 3 & 24.298 & 5.794 & .581 & .171 & .406 & -.030 & -12.566 \\
\hline 4 & 24.277 & 6.389 & .627 & .187 & .437 & -.032 & -13.752 \\
\hline 5 & 24.277 & 6.435 & .631 & .188 & .439 & -.032 & -13.845 \\
\hline 6 & 24.277 & 6.435 & .631 & .188 & .439 & -.032 & -13.846 \\
\hline
\end{tabular}

Dari kedua tabel diatas menunjukkan perbandingan antar nilai $-2 \quad \log$ likelihood awal dengan -2 log likelihood akhir. Pada -2 log likelihood awal menunjukkan angka -2 log likelihood adalah 34.296, sedangkan pada -2 log likelihood akhir menunjukkan angka 24.277, adanya penurunan nilai ini mengindikasikan bahwa model regresi ini baik.

2) Cox and Snell's $R$ Square dan Nagelkereke's $R$ square Cox and Snell's $R$ Square merupakan ukuran yang mencoba meniru ukuran R2 pada multiple regression yang didasarkan pada teknik estimasi likelihood dengan nilai maksimum kurang dari 1 sehingga sulit diinterprestasikan (Ghozali, 2006).

Nagelkerke's $R$ Square merupakan modifikasi dari koefisien Cox and Snell's untuk memastikan bahwa nilainya bervariasi dari 0 (nol) sampai 1 (satu). Hal ini 
dilakukan dengan cara membagi nilai Cox and Snell's $R$ Square dengan nilai maksimumnya. Berikut ini adalah hasil pengujian Cox and Snell's :

Tabel 4. Hasil Pengujian Cox and Snell's Model Summary

\begin{tabular}{|l|r|r|r|}
\hline Step & -2 Log likelihood & $\begin{array}{c}\text { Cox \& Snell R } \\
\text { Square }\end{array}$ & $\begin{array}{l}\text { Nagelkerke R } \\
\text { Square }\end{array}$ \\
\hline 1 & $24.277^{\mathrm{a}}$ & .330 & .442 \\
\hline
\end{tabular}

Nilai Nagelkerke's $R$ Square sebesar 0.442 menunjukkan bahwa variabilitas variabel dependen dapat dijelaskan oleh variabilitas variabel independen sebesar 44,2\% dan 55,8\% dapat dijelaskan oleh variabel lain di luar model.

3) Matrik Klasifikasi

Prediksi ketepatan model juga dapat menggunakan matrik klasifikasi yang menhitung nilai estimasi yang benar (correct) dan salah (incorrect) pada variabel dependen. Matrik klasifikasi akan menunjukkan kekuatan prediksi dari model regresi untuk memprediksi kemungkinan terjadinya praktik konservatisme. Hasil klasifikasi disajikan pada tabel berikut :

Tabel 5. Hasil Uji Matrik Klarifikasi

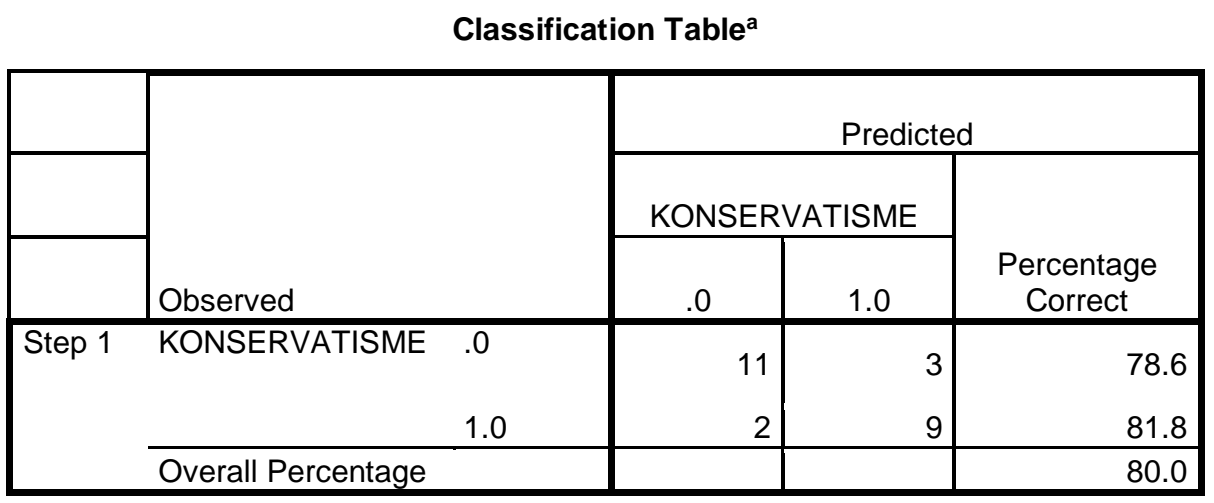

Berdasarkan tabel diatas, menunjukkan bahwa perusahaan yang tidak menggunakan konservatisme adalah 14 perusahaan, 11 perusahaan atau 78,6\% secara tepat dapat diprediksikan oleh model regresi logistik ini, dan 3 perusahaan tidak tepat diprediksikan oleh model ini. Sedangkan dari 11 perusahaan yang mengalami konservatisme, 9 sampel atau $81,8 \%$ perusahaan dapat tepat dengan diprediksikan oleh model regresi ini. Secara keseluruhan berarti bahwa $11+9=$ 
20 perusahaan dari 25 perusahaan atau $80 \%$ sampel dapat diprediksikan dengan tepat oleh model regresi logistik ini. Tingginya persentase ketepatan tabel klasifikasi tersebut mendukung tidak adanya perbedaan yang signifikan terhadap data hasil prediksi dan data observasinya yang menunjukkan sebagai model regresi logistik yang baik.

\section{b. Pengujian Signifikansi Koefisien Regresi}

Pengujian hipotesis mengguna kan model regresi logistik. Regresi logistik digunakan untuk menguji pengaruh kepemilikan manajerial, kepemilikan publik, debt covenant, growth opportunities dan intensitas modal terhadap pilihan konservatisme akuntansi. Hasil pengujian hipotesis disajikan pada tabel 4.15 berikut :

Tabel 6. Hasil Pengujian Signifikansi Koefisien Regresi

Variables in the Equation

\begin{tabular}{|cl|r|r|r|r|r|r|}
\hline & \multicolumn{1}{|c|}{ B } & \multicolumn{1}{c|}{ S.E. } & \multicolumn{1}{c|}{ Wald } & df & \multicolumn{1}{c|}{ Sig. } & \multicolumn{1}{c|}{$\operatorname{Exp(B)}$} \\
\hline Step 1a & KM & .631 & .372 & 2.877 & 1 & .090 & 1.880 \\
& .188 & .146 & 1.651 & 1 & .199 & 1.207 \\
KP & .439 & .253 & 3.018 & 1 & .082 & 1.551 \\
DC & -.032 & .018 & 3.220 & 1 & .073 & .969 \\
GO & -13.846 & 9.863 & 1.971 & 1 & .160 & .000 \\
IM & 6.435 & 5.586 & 1.327 & 1 & .249 & 623.481 \\
\hline
\end{tabular}

Dari tabel diatas dapat dilihat bahwa nilai konstanta adalah 6,435 , koefisien KM sebesar 0,631, koefisien KP sebesar 0,188, koefisien DC sebesar 0,439, koefisien GO sebesar -0,032 dan koefisien IM sebesar -13,846. Model regresi yang terbentuk berdasarkan nilai estimasi parameter dalam Variables in The Equation adalah sebagai berikut :

$L N \frac{p}{1-p}=6,435+0,631 \mathrm{KM}+0,188 \mathrm{KP}+0,439 \mathrm{DC}-0,032 \mathrm{GO}-13,846 \mathrm{IM}$ 

a) Uji Hipotesis

- Pengujian Parsial. Berdasarkan tabel 4.15 didapat hasil Uji Hipotesis sebagai berikut :

1) Koefisien Kepemilikan Manajerial (X1) adalah positif sebesar 0,631 dengan signifikansi 0,090 artinya hipotesis pertama (H1) pada penelitian diterima karena nilai signifikansi $<0,1$ dengan demikian dapat dikatakan Kepemilikan Manajerial berpengaruh signifikan terhadap Konservatisme Akuntansi.

2) Koefisien Kepemilikan Publik (X2) adalah positif sebesar 0,188 dengan signifikansi 0,199 artinya hipotesis kedua (H2) pada penelitian ditolak karena nilai signifikansi > 0,1 dengan demikian dapat dikatakan Kepemilikan Publik tidak berpengaruh signifikan terhadap Konservatisme Akuntansi.

3) Koefisien Debt Covenant (X3) adalah positif sebesar 0,439 dengan signifikansi 0,082 artinya hipotesis ketiga (H3) pada penelitian diterima karena nilai signifikansi $<0,1$ dengan demikian dapat dikatakan Debt Covenant berpengaruh signifikan terhadap Konservatisme Akuntansi.

4) Koefisien Growth Opportunities (X4) adalah negatif sebesar -0,032 dengan signifikansi 0,073 artinya hipotesis keempat (H4) pada penelitian diterima karena nilai signifikansi $<0,1$ dengan demikian dapat dikatakan Growth Opportunities berpengaruh signifikan terhadap Konservatisme Akuntansi.

5) Koefisien Intensitas Modal (X5) adalah negatif sebesar -13,846 dengan signifikansi 0,160 artinya hipotesis kelima (H5) pada penelitian ini ditolak karena nilai signifikansi > 0,1 dengan demikian dapat dikatakan Intensitas Modal tidak berpengaruh signifikan terhadap Konservatisme Akuntansi.

\section{Pembahasan}

a. Pengaruh Kepemilikan Manajerial Terhadap Konservatisme Akuntansi

Hasil pengujian regresi logistik menunjukkan bahwa variabel Kepemilikan Manajerial (KM) berpengaruh terhadap konservatisme akuntansi. Hal ini dapat dilihat dari uji hipotesis dimana tingkat signifikansi KM menunjukkan nilai 0,090, 
dimana nilai tersebut lebih kecil dari tingkat signifikansi yaitu 0,1 , dengan demikian penelitian ini menerima hipotesis pertama $(\mathrm{H} 1)$ yang menyatakan bahwa Kepemilikan Manajerial berpengaruh terhadap konservatisme akuntansi..

b. Pengaruh Kepemilikan Publik Terhadap Konservatisme Akuntansi

Hasil pengujian regresi logistik menunjukkan bahwa variabel Kepemilikan Publik (KP) tidak berpengaruh terhadap konservatisme akuntansi. Hal ini dapat dilihat dari uji hipotesis dimana tingkat signifikansi KP menunjukkan nilai 0,199, dimana nilai tersebut lebih besar dari tingkat signifikansi yaitu 0,1 , dengan demikian penelitian ini menolak hipotesis kedua $(\mathrm{H} 2)$ yang menyatakan bahwa Kepemilikan Publik berpengaruh terhadap konservatisme akuntansi.

c. Pengaruh Debt Covenant Terhadap Konservatisme Akuntansi

Hasil pengujian regresi logistik menunjukkan bahwa variabel Debt Covenant (DC) berpengaruh terhadap konservatisme akuntansi. Hal ini dapat dilihat dari uji hipotesis dimana tingkat signifikansi DC menunjukkan nilai 0,082, dimana nilai tersebut lebih kecil dari tingkat signifikansi yaitu 0,1. Dengan demikian penelitian ini menerima hipotesis ketiga (H3) yang menyatakan bahwa Debt Covenant berpengaruh terhadap konservatisme akuntansi.

d. Pengaruh Growth Opportunities Terhadap Konservatisme Akuntansi

Hasil pengujian regresi logistik menunjukkan bahwa variable Growth Opportunities (GO) berpengaruh terhadap konservatisme akuntansi. Hal ini dapat dilihat dari uji hipotesis dimana tingkat signifikansi GO menunjukkan nilai 0,073, dimana nilai tersebut lebih kecil dari tingkat signifikansi yaitu 0,1. dengan demikian penelitian ini menerima hipotesis keempat (H4) yang menyatakan bahwa Growth Opportunities berpengaruh terhadap konservatisme akuntansi.

e. Pengaruh Intensitas Modal Terhadap Konservatisme Akuntansi

Hasil pengujian regresi logistik menunjukkan bahwa variable Intensitas Modal (IM) tidak berpengaruh terhadap konservatisme akuntansi. Hal ini dapat dilihat dari uji hipotesis dimana tingkat signifikansi GO menunjukkan nilai 0,160, dimana nilai tersebut lebih besar dari tingkat signifikansi yaitu 0,1. dengan demikian penelitian ini menolak hipotesis kelima (H5) yang menyatakan bahwa Intensitas Modal berpengaruh terhadap konservatisme akuntansi. 


\section{KESIMPULAN}

Berdasarkan hasil penelitian yang telah dilakukan mengenai faktor-faktor yang mempengaruhi konservatisme akuntansi pada perusahaan manufaktur sektor Makanan dan Minuman di Bursa Efek Indonesia (BEI) untuk tahun 2011-2015, maka dapat ditarik kesimpulan bahwa dari kelima variabel yaitu kepemilikan manajerial, kepemilikan publik, debt covenant, growth opportunities dan intensitas modal, didapat tiga variabel yang mempunyai pengaruh signifikan terhadap konservatisme akuntansi dengan nilai signifikansi masing-masing variabel yang berada dibawah 0,1 yaitu Kepemilikan Manajerial dengan signifikansi 0,090, Debt Covenant dengan signifikansi 0,082, Growth Opportunities dengan signifikansi 0,073. Sedangkan dua variabel lain tidak berpengaruh signifikan terhadap konservatisme akuntansi, dengan nilai signifikansi masing-masing variabel yang berada diatas 0,1 yaitu Kepemilikan Publik dengan signifikansi 0,199 dan Intensitas Modal dengan signifikansi 0,249.

\section{IMPLIKASI}

Penelitian ini masih jauh dari sempurna, oleh karena itu ada beberapa hal yang menjadi keterbatasan penelitian ini, yaitu sebagai berikut:

1) Koefisien determinasi (Nagelkerke $R$ Square) adalah sebesar 0,442 yang berarti variabilitas variabel dependen yang dapat dijelaskan oleh variabel independen hanya sebesar $44,2 \%$, sedangkan $55,8 \%$ dijelaskan oleh variabel lain di luar model penelitian. Hal ini berarti masih ada variabel lain yang perlu diidentifikasi untuk menjelaskan Konservatisme Akuntansi. Variabel lain yang bisa digunakan dalam penelitian ini misalnya Kepemilikan Institusional, Biaya Politis dan Pajak, serta Biaya litigasi.

2) Pengukuran variabel Debt Covenant bisa juga dihitung dengan rasio Short Term Debt to Total Asset atau bisa juga dihitung dengan rasio Total Debt to Total Asset. Pengukuran variabel Growth Opportunities selain bisa dihitung dengan rasio Market to Book Value of Equity bisa juga digunakan rasio Market to Book Value of Asset.

3) Bila dibandingkan antara hasil penelitian terdahulu dan hasil penelitian ini dapat dibuktikan bahwa faktor Kepemilikan Manajerial memiliki kemungkinan yang sangat besar untuk mempengaruhi penerapan Konservatisme Akuntansi 
pada suatu perusahaan. Bisa dilihat dari penelitian yang dilakukan oleh Widyaningrum (2008) dan Resti (2012), dimana hasilnya sama dengan hasil penelitian ini, yaitu faktor Kepemilikan Manajerial berpengaruh positif terhadap Konservatisme Akuntansi

\section{DAFTAR PUSTAKA}

Alfina, Y. 2006. "Creative Accounting: Ditinjau dari Teori Akuntansi Positif dan Teori Keagenan”. Mandiri. 9: 45-54

Anonim. 2015. Pedoman Penyusunan Tugas Akhir. Sekolah Tinggi Ilmu Ekonomi "Mandala" Jember.

Ardina, Ayu Martaning Yogi. 2012. Penggunaan perspektif Positive Accounting Theory terhadap konservatisme akuntansi di indonesia (Studi empiris perusahaan manufaktur yang terdaftar di BEI periode 2003-2010). Skripsi: Universitas Diponegoro.

Belkaoui and Ahmed. 2006. Accounting Theory. Edisi Kelima, Terjemahan Ali Akbar Yulianto dan Risnawati Dernauli, Salemba Empat, Jakarta.

Deviyanti, Dyahayu Artika. 2011. Analisis faktor-faktor yang mempengaruhi penerapan Konservatisme dalam Akuntansi (studi pada perusahaan manufaktur yang terdaftar di BEI periode 2009-2010). Kajian Bisnis dan Manajemen Vol 8 No 2.

Dewi, AAA. Ratna. 2003, "Pengaruh Konservatisme Laporan Keuangan terhadap Earnings Response Coeffisient”, Simposium Nasional Akuntansi VI, Surabaya: 507-525.

Astarini,dwi. 2011. Analisis Faktor-Faktor yang Mempengaruhi Pilihan Perusahaan Terhadap Konservatisme Akuntansi. Penelitian Fakultas Ekonomi Universitas Pembangunan Nasional "Veteran" Jakarta.

Ghozali, Imam. 2016. Aplikasi Analisis Multivariate dengan Program SPSS, Edisi kedelapan. Badan Penerbit Universitas Diponegoro (BPUD). Semarang

Gideon. 2005. Kualitas Laba: Studi Pengaruh Mekanisme Corporate Governace dan Dampak Manajemen Laba dengan Menggunakan Analisis Jalur. Simposium Nasional Akuntansi VIII.

Ikatan Akuntan Indonesia, 2014, Standar Akuntansi Keuangan per 1 Januari 2015, Salemba Empat, Jakarta. 
Kieso, E Donald and Jerry, J. Weygan Dt. 2006. Akuntansi Intermediate. Penerjemah Wibowo, Herman. Binarupa Akasara. Jakarta.

Mayangsari, Sekar dan Wilopo, 2002, "Konservatisme Akuntansi, Value Relevance dan Discretionary Accruals: Implikasi Empiris Model Feltham Ohlson (1996)", Simposium Nasional Akuntansi IV: 685-708.

Nugroho, Deffa Agung. 2012. Pengaruh struktur kepemilikan manajerial, debt covenant, tingkat kesulitan keuangan perusahaan, dan resiko litigasi terhadap konservatisme akuntansi (studi empiris pada perusahaan manufaktur yang terdaftar di BEI periode 2008-2010). Skripsi Universitas Diponegoro.

Penman, S. 2001. Financial Statement Analysis and Equity Valuation. Mc. Graw Hill. Boston.

Rahmawati, Fitri. 2010. Pengaruh Karakteristik Dewan Sebagai Salah Satu Mekanisme Corporate Governance Terhadap Konservatisme Akuntansi Di Indonesia (studi empiris pada perusahaan manufaktur yang terdaftar di BEI periode 2005-2008).SkripsiUniversitas Diponegoro.

Sari, Dahlia, 2004, "Hubungan antara Konservatisme Akuntansi dengan Konflik Bondholders-Shareholders Seputar Kebijakan Dividen dan Peringkat Obligasi Perusahaan", Simposium Nasional Akuntansi VII, Denpasar: 1043-1058.

Sekaran, Uma (2003), Research Methods For Business: A Skill Building Aproach, New York-USA: John Wiley and Sons, Inc

Suharli, Michael and Megawati Oktarina. 2009. Memprediksi Tingkat Pengembalian Investasi Pada Equity Securities Melalui Rasio Profitabilitas, Likuiditas, dan Hutang pada Perusahaan Publik di Jakarta. SNA VIII : Ikatan Akuntan Indonesia.

Wardhani, Ratna. 2008. Tingkat Konservatisme Akuntansi Di Indonesia Dan Hubungannya Dengan Karakteristik Dewan Sebagai Salah Satu Mekanisme Corporate Governance. SNA 11 : Ikatan Akuntan Indonesia.

Watts, Ross L, 2003, “Conservatism in Accounting”, Working Paper, University of Rockhester: New York.

Widya, 2004, “Analisis Faktor-Faktor yang Mempengaruhi Pilihan Perusahaan 
Terhadap Akuntansi Konservatif”, Simposium Nasional Akuntansi VII, Denpasar: 709-724. 